\title{
Presidential Rhetoric and Power in a Historical Perspective
}

\section{Magne Dypedahl}

University of South-Eastern Norway

\begin{abstract}
This article explores some of the developments of rhetorical leadership over the past century, focusing particularly on the modern presidency, commonly understood as beginning with Franklin D. Roosevelt. The first research question is whether Richard Neustadt's (1960) seminal book Presidential Power is still valid as a thesis of presidential power in light of the concept of the rhetorical presidency, which became a dominant approach to presidential studies in the 1980s. Although the strategy of "going public" is used increasingly in presidential leadership, the conclusion of this article is that Neustadt's bargaining theory, or the strategy of "going Washington", is still valid when it comes to the relationship between the president and Congress, provided popular rhetoric is integrated into a bargaining perspective. The second research question is how the State of the Union Addresses have changed during the course of the modern presidency. This includes an analysis of selected State of the Union Addresses between 1934 and 2020. On the basis of some linguistic features and rhetorical techniques (the use of pronouns, the opening address and the acknowledgment of invited guests) they are considered to illustrate the change of presidential rhetoric into what may seem like a permanent campaign.
\end{abstract}

Keywords: rhetorical leadership, Presidential power, State of the Union Adresses

\section{Introduction}

Rhetorical leadership has gradually become a dominant feature of the American presidency. Not least the quantity of public appeals has increased dramatically over the past century. This development has surely been encouraged by advances in media technology, from newsreels and radio to Facebook and Twitter, but the question is whether the use of public appeals also has changed a president's legislative influence on Congress, and consequently the balance between the executive and the legislative branch. The Founders clearly did not expect or intend public appeals to be a major 
tool of presidential power. In The Federalist, for example, James Madison states that "every appeal to the people would carry an implication of some defect in the government", ${ }^{1}$ whereas Alexander Hamilton uses history to warn against leaders who pay "an obsequious court to the people" and turn to demagoguery. ${ }^{2}$ However, the Constitution does not prevent presidents from trying to shape public opinion, and there has never been a truly nonrhetorical presidency. Nonetheless, Woodrow Wilson (1913-1921) is often considered to be the first rhetorical president. One reason for this is that he reinterpreted the constitutional principles of not letting public opinion play a major role in the relationship between the executive branch and the legislative branch. ${ }^{3}$ It was also Wilson who in 1913 revived the tradition of personally delivering State of the Union Addresses to Congress. ${ }^{4}$

Different types of public appeals have been investigated in many fields of study, such as political science, history and rhetoric. For that reason, a study of presidential rhetoric is also well suited for an interdisciplinary American Studies approach by drawing on several relevant fields of study. This article will explore some of the developments of rhetorical leadership over the past century, but mainly focus on the modern presidency, commonly understood as beginning with the inauguration of Franklin D. Roosevelt in 1933. This conceptualization is based on factors such as the presidents' use of formal and informal power to make decisions on their own, the role as "chief agenda setters in federal-level policy-making", the size of the White House bureaucracy and the visibility of president compared to other political actors. ${ }^{5}$ Two research questions will be discussed in the following: (1) Is Richard Neustadt's famous book Presidential Power from 1960 still valid as a thesis of presidential power in light of how presidential rhetoric is used today?, and (2) How have the State of the Union Addresses changed during the course of the modern presidency? The discussion of the last question will include an analysis of selected State of the Union Addresses between 1934 and 2020 .

1 James Madison, "The Federalist No. 49," in The Federalist, ed. Jacob E. Cooke (Middletown, CT: Wesleyan University Press, 1788/1961), 56.

2 Alexander Hamilton, "The Federalist No. 1," in The Federalist, ed. Jacob E. Cooke (Middletown, CT: Wesleyan University Press, 1788/1961), 6.

3 Jeffrey K. Tulis, The Rhetorical Presidency (Princeton, NJ: Princeton University Press, 1987), 118.

4 Tulis, The Rhetorical Presidency, 56.

5 Fred I. Greenstein, "Introduction: Toward a Modern Presidency," in Leadership in the Modern Presidency, ed. Fred I. Greenstein (Cambridge, MA: Harvard University Press, 1988), 4. 
The main purpose of including State of the Union Addresses in this article is to illustrate the change of presidential leadership into what may seem like a permanent campaign. A paradox of this permanent campaign is identified in George C. Edwards III's book On Deaf Ears: The Limits of the Bully Pulpit (2003): "Yet even if presidents succeed in obtaining support for themselves and their policies, the potential of such a strategy is limited" ${ }^{6}$ It makes presidents visible, but it may in fact have very little effect on their legislative power in relation to Congress. This seems to stand in contrast to some of the scholarship on the rhetorical aspect of the presidency, which has been influential since the 1980s. In 1981, the term "rhetorical presidency" was coined in a seminal article entitled "The Rise of the Rhetorical Presidency", which argues that the modern presidency has become a rhetoric-based institution.? One of its authors, Jeffrey K. Tulis, developed this idea further in The Rhetorical Presidency (1987), which is now regarded as a classic study. There is no doubt that the presidency is based more on rhetoric than ever. However, it is the limited potential of this strategy in relation to Congress that serves as a backdrop for the current article.

\section{Richard Neustadt's thesis of presidential power}

Prior to Richard Neustadt, scholarship on the presidency was dominated by the institutional approach of Edward S. Corwin, who published the first edition of The President: Office and Powers in 1940. Corwin emphasized the "legalistic" and constitutional authority of the president. Thus, Neustadt revolutionized the study of the presidency by using behaviorism as a source of inspiration and focusing on personality rather than institutional power. ${ }^{8}$ Indeed, personality is presented as a way of making up for a lack of prerogative power.

With a background as a public servant in the Bureau of the Budget and in the White House, Neustadt may have been more concerned about making his book Presidential Power useful to political practitioners than develop-

6 George C Edwards III, On Deaf Ears: The Limits of the Bully Pulpit (New Haven: Yale University Press, 2003), 21.

7 James W. Ceaser et al., "The Rise of the Rhetorical Presidency," Presidential Studies Quarterly 11, no. 2 (1981), http://www.jstor.org/stable/27547683.

8 See Mitchel A. Sollenberger, "The Law Presidential Studies, Behavioralism, and Public Law," Presidential Studies Quarterly 44, no. 4 (2014): 760, https://doi.org/10.1111/psq.12159. 
ing scholarly theories. ${ }^{9}$ However, Neustadt's thesis of presidential power, "the power to persuade", may be regarded as a theory in the sense that it can be described as a bargaining model of presidential power. ${ }^{10}$ Neustadt further describes presidential power in the following manner:

Effective influence for the man in the White House stems from three related sources: first are the bargaining advantages inherent in his job with which to persuade other men that what he wants of them is what their own responsibilities require them to do. Second are the expectations of those other men regarding his ability and will to use the various advantages they think he has. Third are those men's estimates of how his public views him and of how their publics may view them if they do what he wants. In short, his power is the product of his vantage points in government, together with his reputation in the Washington community and his prestige outside. ${ }^{11}$

In his book, Neustadt uses the word "power" in the singular and in a very general sense. Although he seems less concerned about specific constitutional powers or specific goals, his view on personality and presidential power definitely relates to the balance between the executive and the legislative branch. Neustadt even told a Senate committee in 1963 that "while the Constitution had contemplated that judgements on peace and war should come from the President and Congress combined, this could no longer work in the nuclear age ...". ${ }^{12}$ As Arthur Schlesinger, Jr. argues in The Imperial Presidency (1973), the Vietnam War and the execution of power by Lyndon B. Johnson and Richard Nixon proved a strong presidency to be problematic, which was also recognized by Congress in passing the War Powers Resolution in 1973. However, this struggle for power mainly relates to foreign policy or the strategy of "going international". Neustadt's thesis rather relates the insider's game of bargaining or the strategy of "going Washington". ${ }^{13} \mathrm{He}$ has been criticized for being too concerned with the president as a person and his ability to persuade, whereas it can be argued that presidential power is just as much based on prerogative as on

9 Charles O. Jones, "RICHARD E. NEUSTADT: Public Servant as Scholar," Annual Review of Political Science 6, no. 1 (2003): 2, https://doi.org/10.1146/annurev.polisci.6.121901.085848.

10 Richard E. Neustadt, Presidential Power: The Politics of Leadership (New York: Wiley, 1960), 60.

11 Neustadt, Presidential Power: The Politics of Leadership, 179.

12 Arthur M. Schlesinger, The Imperial Presidency (Boston: Houghton Mifflin, 1973), 166.

13 See Michael A. Genovese, Presidential Leadership in an Age of Change, The presidential briefings series, (New Brunswick, NJ: Transaction Publishers, 2016). 
persuasion, in addition to factors such as party affiliation. ${ }^{14}$ With regard to persuasion, a president does not have the time to bargain with everyone in Congress, and extensive bargaining is in many cases not needed in order to secure a majority. ${ }^{15}$ Even if Neustadt overrated bargaining, however, it does not follow that the insider's game can be replaced by the concept of "going public" as a model of presidential leadership in relationship to Congress.

\section{Recognition of a rhetorical presidency}

Two decades after the publication of Presidential Power, Ronald Reagan (1981-1989) was elected president, and his administration was an obvious source of inspiration for the many scholars who became more interested in the use of presidential rhetoric, including Jeffrey K. Tulis. The Reagan administration was also open about its strategies of managing public opinion in their policy making. ${ }^{16}$ According to Tulis, Woodrow Wilson, the first rhetorical president, wanted the executive to have a more active role in relation to Congress and the public, and called the separation of powers a defect of the political system. ${ }^{17}$ By the 1980 s, it was clear that presidential leadership appeared very different from how it is viewed in the original Constitution. For that reason, Tulis refers to the understanding of the presidency as active leadership of public opinion as a "second constitution". ${ }^{18}$ Nevertheless, Tulis does not seem to refute many of the basic elements in Neustadt's bargaining thesis.

Another classic study from the 1980s, Samuel Kernell's Going Public: New Strategies of Presidential Leadership (1986), in contrast, suggests that the thesis needs to be replaced. Kernell writes that, "[g]oing public violates bargaining in many ways" and if [p]racticed in a dedicated way, ... it may displace bargaining". ${ }^{19}$ The argument is that the public appeals can be used

14 See Harry A. Bailey, "Neustadt's Thesis Revisited: Toward the Two Faces of Presidential Power," Presidential Studies Quarterly 11, no. 3 (1981): 356, http://www.jstor.org/stable/27547714.

15 See Bailey, "Neustadt's Thesis Revisited: Toward the Two Faces of Presidential Power," 354.

16 Mark J. Rozell, “In Reagan's Shadow: Bush's Antirhetorical Presidency,” Presidential Studies Quarterly 28, no. 1 (1998): 127, http://www.jstor.org/stable/27551835.

17 Tulis, The Rhetorical Presidency, 119.

18 Tulis, The Rhetorical Presidency, 18.

19 Charles U. Zug, "The Rhetorical Presidency Made Flesh: A Political Science Classic in the Age of Donald Trump," Critical Review 30, no. 3-4 (2018/10/02 2018): 350, https://doi.org/10.1080/08913811.2018.156 7983. 
strategically to gain support for a political issue, which in turn will persuade Congress to agree with the executive.

The expression "going public" is by any account a good description of the strategy of leadership modern presidents use. However, there are different ways of studying or assessing this strategy. Two of the major constructs can be described as the study of the rhetorical presidency versus the study of presidential rhetorical. According to Martin J. Medhurst, "one is narrow and theory-dependent, the other broad and practice-dependent; one rooted in the discipline of political science, the other most at home in speech communication ...". ${ }^{20}$ For that reason, a general theory of presidential power rooted in the field of political science is not necessarily challenged by the many studies that are rooted in the discipline of rhetoric.

\section{The rhetorical presidency and presidential power: on balance}

The presidency we can observe today is very different from the Founders' idea of a chief administrator. There is no doubt that public appeals have increasingly become one of the principal tools in governing the nation, and many aspects of Neustadt's model of presidential power can be said to be inadequate in light of a rhetorical presidency. ${ }^{21}$ There is some evidence that public appeals can have an effect on the president's influence as legislator. A study of the nationally televised addresses of Presidents Eisenhower through Clinton by Brandice Canes-Wrone, for example, concludes that "presidents obtain significant legislative influence by promoting their proposals" in these speeches". However, the study also finds that "unpopular proposals are almost never the subject of appeals" .22 In other words, the finding is that presidents tend to go public on issues when their position is popular, whereas other bargaining strategies are chosen in other cases. The study even finds that the popularity of the proposal itself and a unified government is far more important than the personal popularity of the president. Another study, investigating the reactions of people right after having

20 Martin J. Medhurst, "Introduction - A Tale of two Constructs: The Rhetorical Presidency and Presidential Rhetoric," in Beyond the Rhetorical Presidency, ed. Martin J. Medhurst (College Station: Texas A\&M University Press, 1996), xi.

21 See Benjamin A. Kleinerman, "The Constitutional Ambitions of James Madison's Presidency," Presidential Studies Quarterly 44, no. 1 (2014), https://doi.org/10.1111/psq.12085.

22 Brandice Canes-Wrone, “The President's Legislative Influence from Public Appeals," American Journal of Political Science 45, no. 2 (2001): 326, https://doi.org/10.2307/2669343. 
watched a press conference and an address to the nation by Ronald Reagan, concludes that the reactions reflect the degree of support for the Reagan..$^{23}$

Although it is admittedly difficult to measure the effect of public appeals, for example Nielsen Media Research reports and Nielsen ratings supply researchers with data about how messages are received by various audiences. ${ }^{24}$ Still, in his study Deaf Ears: The Limits of the Bully Pulpit, Edwards concludes that "presidents typically do not succeed in their efforts to change public opinion". ${ }^{25}$ Quite simply, there a number of challenges that the strategy of going public does not seem solve. John P. Burke, for example, concludes that "[g]oing public is not a panacea for the deadlock in Washington politics". ${ }^{26}$

Generally, there is very little evidence that the strategy of "going public" can replace the strategy of "going Washington" with regard to a president's influence on Congress. However, in order to claim that Neustadt's thesis is still valid on many accounts, it is necessary to integrate the extensive use of public appeals and reliance on approval ratings into the thesis. Neustadt focused on a president's "personal capacity to influence the conduct of men who make up the government". ${ }^{27}$ The question is if approval ratings can be said to influence Congress by giving the president what Neustadt refers to in the quote above as "prestige".

In fact, both "Neustadt and Edwards argue that presidential approval (or "prestige") should be viewed at strategic influence, a factor that may affect the outcome of every case, but that will not necessarily determine the outcome in a specific case. ${ }^{28}$ As quoted above, Neustadt describes presidential power as "the product of his vantage points in government, together with his reputation in the Washington community and his prestige outside". ${ }^{29}$ One interpretation of this is that public appeals can have an effect on his prestige outside Washington, which in turn can have an effect on his prestige in Washington. An important concept in this regard is what Neustadt

23 Roberta Glaros and Bruce Miroff, "Watching Ronald Reagan: Viewers' Reactions to the President on Television," Congress \& the Presidency 10, no. 1 (1983), https://doi.org/10.1080/ 07343468309508025.

24 See Edwards III, On Deaf Ears: The Limits of the Bully Pulpit, 190.

25 Edwards III, On Deaf Ears: The Limits of the Bully Pulpit, 241.

26 John P. Burke, Presidential Power: Theories and Dilemmas (Boulder, CO: Westview Press, 2016), 130.

27 Neustadt, Presidential Power: The Politics of Leadership, 2.

28 Edwards III, On Deaf Ears: The Limits of the Bully Pulpit, 21.

29 Neustadt, Presidential Power: The Politics of Leadership, 179. 
refers to as "the dominant tone" in Washington..$^{30}$ Neustadt also proposes that the Washington community "do not see alone, they see together. What they think of him is likely to be much affected by the things they see alike". ${ }^{31}$ It seems likely that this dominant tone in Washington, which in itself is an interesting topic of research, can be an important source of presidential power. ${ }^{32}$ Neustadt also writes that the "professional reputation of a President in Washington is made or altered by the man himself". ${ }^{33}$

In conclusion, a number of factors will determine the influence of a president. Nevertheless, presidential rhetoric and going public can be integrated in Neustadt's theory by assuming that the dominant tone in Washington is important to presidential power, and that this dominant tone is affected by public opinion. Even though the theory is still valid, however, there is no doubt that the reliance on public appeals has changed the presidency. While making politics in general much more president-centered, other consequences may be lack of deliberation and incoherent policies and that a president can use rhetorical tools to create a sense of crisis. As David A. Crockett writes, "a tool once reserved for crisis politics has become routine, making the sense of crisis politics the norm". ${ }^{34}$ Inevitably, such a media reality will affect the relationship between the executive and the legislative branch. Although State of the Union Addresses only represent one aspect this relationship, the delivery of the addresses can illustrate the development of the rhetorical aspect of the modern presidency.

\section{State of the Union Addresses: An introduction}

In order to get a better understanding of the impact of public appeals on the relationship between the executive and the legislative branch during the modern presidency, three aspects of the State of the Union Addresses from 1934 to 2020 will be examined. Firstly, I will study the use of opening words, such as "Mr. Speaker, Mr. Vice President, Members of Congress,

30 Neustadt, Presidential Power: The Politics of Leadership, 62.

31 Neustadt, Presidential Power: The Politics of Leadership, 63.

32 See Charles O. Jones, "Professional Reputation and the Neustadt Formulation," Presidential Studies Quarterly 31, no. 2 (2001): 80, https://doi.org/10.1111/j.0360-4918.2001.00171.x.

33 Neustadt, Presidential Power: The Politics of Leadership, 80.

34 David A. Crockett, “"The Rhetorical Presidency”: Still Standing Tall," Presidential Studies Quarterly 39, no. 4 (2009): 936, http://www.jstor.org/stable/41427430. 
my fellow Americans". ${ }^{35}$ According to Paul Chilton, this establishes "extra-textual relationship between speaker and hearers such that the hearers are postulated as present in the same (political) space and as proximate to the speaker". ${ }^{36}$ Secondly, I will investigate if there have been observable changes in the use of pronouns because these can conceptualize "group identity, coalitions, parties, and the like, either as insiders or outsiders". ${ }^{37}$ Thirdly, I will discuss how the State of the Union Addresses are affected as a genre by the acknowledgment and rhetorical use of invited, ordinary citizens in the speeches.

State of the Union Addresses are particularly relevant for the purpose of this investigation because they represent a formal and mandatory aspect of the relationship between the executive and the legislative branch. Article II, Section 3 of the U.S. Constitution states that the president "shall from time to time give to the Congress information of the state of the union and recommend to their consideration such measures as he shall judge necessary and expedient". The first two first presidents, George Washington and John Adams, delivered brief oral statements to Congress, but the third president, Thomas Jefferson, started a long tradition of sending the annual messages to Congress in writing. As mentioned above, a new tradition was established when Woodrow Wilson began to deliver the messages as oral presentations in $1913 .{ }^{38}$ This introduced the so-called modern era of State of the Union Addresses. ${ }^{39}$

As a rule, the messages since then have been delivered orally. Franklin D. Roosevelt and Dwight D. Eisenhower made exceptions in 1945 and 1956, respectively, when they addressed the nation via radio with a summary of written messages sent to Congress. Likewise, 1973 is an exception because Richard Nixon delivered six messages to Congress accompanied by radio addresses to the general public. Thus, these messages are not included in

35 Barack Obama, "Address before a Joint Session of Congress on the State of the Union " in The American Presidency Project, ed. Gerhard Peters and John T. Woolley (Santa Barbara, CA: University of California, 2015). https://www.presidency.ucsb.edu/documents/address-before-joint-session-the-congress-the-statethe-union-20.

36 Paul A. Chilton, Analysing Political Discourse: Theory and Practice (New York: Routledge, 2004), 139.

37 Chilton, Analysing Political Discourse: Theory and Practice, 56.

38 Tulis, The Rhetorical Presidency, 56.

39 Ryan L. Teten, "Evolution of the Modern Rhetorical Presidency: Presidential Presentation and Development of the State of the Union Address," Presidential Studies Quarterly 33, no. 2 (2003): 343, https://doi. org/10.1111/j.1741-5705.2003.tb00033.x. 
this study because the aim is to discuss addresses that are presented orally to Congress and a general audience simultaneously. Following the classification of Gerhard Peters and John T. Woolley, ${ }^{40}$ addresses that are delivered right after a president's first inauguration are also excluded because they are not technically regarded as State of the Union Addresses (1981, 1989, 1993, 2001, 2009, and 2017), whereas two speeches delivered right before the presidents left office are included (1969 and 1977). Later presidents have chosen not to deliver State of the Union Addresses in the final days of their presidencies. ${ }^{41}$

Only a selection of addresses will be commented on below to illustrate relevant findings, but the entire corpus of texts that have been investigated comprises 77 addresses from 1934 to 2020 classified as traditional State of the Union Addresses. The average length of these addresses is 5,184 words. ${ }^{42}$ The software program used for the frequency rate of personal pronouns is AntConc. ${ }^{43}$ Although the addresses were called annual messages until 1969, they will all be referred to as State of the Union Addresses below.

\section{Opening words}

The first State of the Union Address in this corpus, Franklin D. Roosevelt's 1934 speech, opens as follows: "Mr. President, Mr. Speaker, Senators and Representatives in Congress". ${ }^{44}$ This clearly indicates that Congress is targeted as the prime audience. Although the State of the Union Addresses were televised from 1947,45 Harry Truman, Dwight D. Eisenhower and John F. Kennedy continue not to include the general public in the opening lines, such as "Mr. President, Mr. Speaker, Members of the Congress of the United States"46 or "Mr. President, Mr. Speaker, Members of the 86th

40 Gerhard Peters and John T. Wooley, "The State of the Union, Background and Reference Table," in The American Presidency Project, ed. Gerhard Peters and John T. Wooley (Santa Barbara, CA: University of California, 1999-2020). https://www.presidency.ucsb.edu/node/324107/.

41 See Peters and Wooley, "The State of the Union, Background and Reference Table."

42 Based on numbers from Peters and Wooley, "The State of the Union, Background and Reference Table."

43 Laurence Anthony, “AntConc," (3.5.8, 2019). https://www.laurenceanthony.net/software/ antconc/.

44 Franklin D. Roosevelt, "Annual Message to Congress “ in The American Presidency Project, ed. Gerhard Peters and John T. Woolley (Santa Barbara, CA: University of California, 1934). https://www.presidency. ucsb.edu/documents/annual-message-congress-4.

45 Peters and Wooley, "The State of the Union, Background and Reference Table."

46 Harry Truman, "Annual Message to the Congress on the State of the Union " in The American Presidency Project, ed. Gerhard Peters and John T. Woolley (Santa Barbara, CA: University of California, 1947). https://www.presidency.ucsb.edu/documents/annual-message-the-congress-the-state-the-union- 15 . 
Congress" ${ }^{47}$ For that reason, it is symbolic when Lyndon B. Johnson starts to include the general public in the opening words in 1964: "Mr. Speaker, Mr. President, Members of the Congress, my fellow Americans". ${ }^{48}$ The change from regarding the general public as a secondary audience to one of two primary audiences is likely to have been gradual, but the targeting of the American people as a primary audience was further strengthened in 1965 when the delivery of the speech was permanently moved to 9 p.m. Eastern time instead of during working hours. ${ }^{49}$

In 1982, Ronald Reagan extended the opening words even further by including "honored guests". ${ }^{50}$ As discussed below, this is when the tradition of acknowledging invited guests is established. George H.W. Bush only uses "honored guests" in his third and last State of Union in $1992,{ }^{51}$ whereas Bill Clinton and George W. Bush use "distinguished guests". ${ }^{52}$ Barack Obama refers to "honored guests" in his first three State of the Union Addresses, but in his fourth he skips any reference to guests in the opening line. This is also continued by Donald Trump, which could be due to the fact that it is now standard procedure with many acknowledged guests, who are also "fellow Americans. It could also be a sign that presidents today relate primarily to these guests and the America people.

47 Dwight D. Eisenhower, "Annual Message to the Congress on the State of the Union " in The American Presidency Project, ed. Gerhard Peters and John T. Woolley (Santa Barbara, CA: University of California, 1960). https://www.presidency.ucsb.edu/documents/annual-message-the-congress-the-state-the-union-6.

48 Lyndon B. Johnson, "Annual Message to the Congress on the State of the Union " in The American Presidency Project, ed. Gerhard Peters and John T. Woolley (Santa Barbara, CA: University of California, 1964). https://www.presidency.ucsb.edu/documents/annual-message-the-congress-the-state-the-union- 25.

49 Peters and Wooley, "The State of the Union, Background and Reference Table."

50 Ronald Reagan, "Address before a Joint Session of Congress Reporting on the State of the Union " in The American Presidency Project, ed. Gerhard Peters and John T. Woolley (Santa Barbara, CA: University of California, 1982). https://www.presidency.ucsb.edu/documents/address-before-joint-session-the-congress-reporting-the-state-the-union- 2 .

51 George H. W. Bush, "Address before a Joint Session of Congress on the State of the Union " in The American Presidency Project, ed. Gerhard Peters and John T. Woolley (Santa Barbara, CA: University of California, 1992). https://www.presidency.ucsb.edu/documents/address-before-joint-session-the-congress-thestate-the-union-0.

52 See for example Bill Clinton, "Address before a Joint Session of Congress on the State of the Union " in The American Presidency Project, ed. Gerhard Peters and John T. Woolley (Santa Barbara, CA: University of California, 1997). https://www.presidency.ucsb.edu/documents/ address-before-joint-session-thecongress-the-state-the-union- 9 . 


\section{Personal pronouns}

The use of personal pronouns can be another indicator of how presidents want to relate to their different audiences. In his 1934 speech, Roosevelt uses the personal pronoun "I" with a frequency rate of 10,8 per 1,000 words (24 times) and "you" with a frequency rate of 5.4 (12 times). "We" has a frequency rate of 15.3 (34 times), and it is either used in a very general sense or referring to the president and Congress: "In this spirit we join once more in serving the American people". ${ }^{53}$ In this case the high frequency of "we" could be an attempt to make Congress identify with the speaker. There was considerable resistance to dramatic New Deal measures also within his own party. At that time, the Democratic party could still be described as a Jeffersonian party with regard to protecting states rights, and many Democrats even criticized Republicans for advocating centralization and spending..$^{54}$

Generally, the use of pronouns in State of the Union Addresses reflects the fact that the president delivers the speech directly to senators and members of Congress. For example, between 1934 and 1941, Roosevelt continues to speak exclusively to Congress. When he uses the personal pronoun "you" he addresses members of Congress, whereas the American people are referred to as "they":

Your task and mine is not ending with the end of the depression. The people of the United States have made it clear that they expect us to continue our active efforts in behalf of their peaceful advancement. ${ }^{55}$

An interesting exception to the general rule is Roosevelt's State of the Union Address in 1942. The frequency rates per 1,000 words of "I" and "you" are low at 3.4 (12 times) and 0.6 (2 times), respectively. However, the new aspect of this speech is that "we" is used with a frequency rate of 21.2 (78 times), and that "we" in this case is used as an inclusive American "we" or ambiguously. This need for specifically involving the nation can be explained by the fact that the speech was delivered the month after Pearl Harbor: "We and those united with us will make those decisions with cour-

53 Roosevelt, "Annual Message to Congress “.

54 Arthur M. Schlesinger, Jr., The Crisis of the Old Order: The Age of Roosevelt, 1919-1933, Francis Parkman Prize ed. (New York: History Book Club, 1957/2002), 282.

55 Franklin D. Roosevelt, "Annual Message to Congress " in The American Presidency Project, ed. Gerhard Peters and John T. Woolley (Santa Barbara, CA: University of California, 1937). https://www.presidency. ucsb.edu/documents/annual-message-congress-1. 
age and determination". His use of "they" refers to "Hitler and his Italian and Japanese chessmen": "They know that victory for us means victory for freedom". ${ }^{56}$ Roosevelt's last two State of the Union Addresses are very similar, referring, for example, to "We Americans". ${ }^{57}$ This does not mean that Congress with their power of the purse would not be his prime audience, but these wartime messages were likely to draw both national and international interest.

After the war, State of the Union Addresses return to normalcy again. In Harry Truman's 1947 State of the Union Address, the frequency rate of "I" is 6.8 per 1,000 words, "you" 1.5 per 1,000 words, and "we" 12.3. Mainly, the use of "we" only includes the president and Congress: "We should enact legislation ...". ${ }^{58}$ The same identification with Congress can also be seen in the way Dwight D. Eisenhower and John F. Kennedy use "I", "you" and "we", as for example: "For you and I are privileged to serve the great Republic ...". 59

A lack of normalcy may be the reason Lyndon B. Johnson's State of the Union in 1964 is atypical. It was delivered less than two months after the assassination of John F. Kennedy. The frequency rate per 1,000 words of "I" is unremarkable at 5.1; the frequency of "you" is as low as 1.9, while the frequency of "we" is as high as 23.3. In addition, the use of "we" is somewhat ambiguous, in that it may or may not include the general public. In 1965, Johnson involves himself more by increasing the frequency rate of "I" to 13.0, whereas of "the frequency rate of "you" is 2.5 and "we" 25.4. In 1969 , he becomes even more personal in his last State of the Union Address in by using "I" with a frequency rate of 24.5. The frequency rate of "you" is 4.6 and "we" 16.3 . The high frequency of "I" seems to reflect a desire to use this opportunity to sum up all his years in office. For example, he refers to the obvious burden of the Vietnam War: "I regret more than any of you

56 Franklin D. Roosevelt, "Annual Message to Congress “ in The American Presidency Project, ed. Gerhard Peters and John T. Woolley (Santa Barbara, CA: University of California, 1942). https://www.presidency. ucsb.edu/documents/state-the-union-address-1.

57 Franklin D. Roosevelt, “Annual Message to Congress “ in The American Presidency Project, ed. Gerhard Peters and John T. Woolley (Santa Barbara, CA: University of California, 1943). https://www.presidency. ucsb.edu/documents/state-the-union-address-0.

58 Truman, "Annual Message to the Congress on the State of the Union ".

59 John F. Kennedy, "Annual Message to the Congress on the State of the Union " in The American Presidency Project, ed. Gerhard Peters and John T. Woolley (Santa Barbara, CA: University of California, 1963). https://www.presidency.ucsb.edu/documents/annual-message-the-congress-the-state-the-union-3. 
know that it has not been possible to restore peace to South Vietnam". ${ }^{60}$

Compared to the sample of State of the Union Addresses above, Donald Trump's 2020 address differs in the sense that there is a fairly high frequency of all the three pronouns. The frequency rate of "I" is as high as 9.6, whereas the frequency rate of "you" and "we" are 11.7 and 15.7, respectively. Furthermore, "you" is often used in warnings to enemies: "You will never escape American justice. If you attack our citizens, you forfeit your life". "We" mainly refers to his own administration: "Three years ago, we launched the great American comeback" ${ }^{61}$ Focusing on achievements or visions of the administration is not different from many other State of the Union Addresses, but there are fewer unifying and bi-partisan uses of pronouns than in the past, and Congress plays a very minor role in this speech.

\section{Invited guests}

The third aspect of the State of the Union Addresses investigated in this article is the acknowledgement of invited guests in the gallery of the House of Representatives. Ronald Reagan was the first president to introduce this practice in 1982 when he mentioned a federal government employee, Lenny Skutnik, who after an airplane crash on the Potomac River "saw a woman lose her grip on the helicopter line, dived into the water and dragged her to safety". ${ }^{62}$ Typically, the guests are everyday heroes, and mentioning their names and what they have done can evoke emotions and encourage empathy. Rhetorically, this introduced more use of pathos in the State of the Union Addresses, which can be described as "the ability to engage emotionally with an audience through empathy, humor or arousing feelings such as fear or hate". ${ }^{63}$

Any acknowledgment of invited guests can be said to be an acknowl-

60 Lyndon B. Johnson, "Annual Message to the Congress on the State of the Union " in The American Presidency Project, ed. Gerhard Peters and John T. Woolley (Santa Barbara, CA: University of California, 1969). https://www.presidency.ucsb.edu/documents/annual-message-the-congress-the-state-the-union-30.

61 Donald J. Trump, "Address before a Joint Session of Congress on the State of the Union " in The American Presidency Project, ed. Gerhard Peters and John T. Woolley (Santa Barbara, CA: University of California, 2020). https://www.presidency.ucsb.edu/documents/address-before-joint-session-the-congress-the-statethe-union-27.

62 Reagan, "Address before a Joint Session of Congress Reporting on the State of the Union ".

63 Jonathan Charteris-Black, Politicians and Rhetoric: The Persuasive Power of Metaphor, 2nd ed. ed. (Basingstoke, Hampshire; New York: Palgrave Macmillan, 2011), 15. 
edgement of the American people. It could also be a recognition of the general public having become the primary audience, or at least just as important as Congress. However, the number of acknowledged guests has increased over the years, and this can affect the structure of the texts, or at least the rhetorical effect of the event. For example, in his 2018 State of the Union Address, Donald Trump acknowledges the presence of a record number of 11 guests. There is almost one guest for each political issue or value included in the speech, and the likely aim of introducing the guests is to send a message to political supporters:

Here tonight is Preston Sharp, a 12-year-old boy from Redding, California, who noticed that veterans' graves were not marked with flags on Veterans Day. He decided all by himself to change that and started a movement that has now placed 40,000 flags at the graves of our great heroes. ... Preston's reverence for those who have served our Nation reminds us of why we salute our flag, why we put our hands on our hearts for the Pledge of Allegiance, and why we proudly stand for the national anthem. ${ }^{64}$

In addition to a general appeal to patriotism, this is likely to have been a comment on athletes who protested against racial injustice in the months before by kneeling when the national anthem was played.

Trump continued the tradition of having a guest for almost every political issue in 2019 and 2020. In 2020 he even invited Sergeant First Class Townsend Williams, who served in Afghanistan, as a surprise guest. His wife, Amy Williams, and her two children, 6-year-old Elliana and 3-yearold Rowan, had been invited to the gallery to be thanked for their sacrifice, and the situation was turned into a very emotional TV moment when the surprise guest was brought out.

\section{Concluding remarks}

Among the three aspects of the State of the Union Addresses that have been investigated in this article, the use of personal pronouns is fairly consistent over time. The simple reason for this could be that the purpose still is to interact with Congress and that the proximity to the senators and members of

64 Donald J. Trump, “Address before a Joint Session of Congress on the State of the Union " in The American Presidency Project, ed. Gerhard Peters and John T. Woolley (Santa Barbara, CA: University of California, 2018). https://www.presidency.ucsb.edu/documents/address-before-joint-session-the-congress-the-statethe-union-25. 
House of Representatives would make it strange not to relate to that group both formally and linguistically. Cases of variation can be explained with reference to contemporary events. The opening words, on the other hand, have been extended to include fellow Americans. An additional two words may not seem dramatic, but they can symbolize the "second constitution" and the introduction of public opinion in the direct interaction between the president and Congress. Today, the primary audience of this formal interaction between the executive and Congress seems to be the American people.

The most dramatic change of State of the Union Addresses may in fact be the acknowledgement of invited guest on the gallery. In rhetoric, it is acceptable to excite "emotional responses that are appropriate to the situation". ${ }^{65}$ However, the use of surprise guests as a rhetorical device can be said to move the genre towards infotainment rather than a formal, political speech. Trump's State of the Union Addresses clearly have all the elements of a partisan political rally in the playbook, but also based on other recent State of the Union Addresses it can be concluded that they can symbolize a change of the presidency into a permanent campaign.

As argued above, the presidency has changed dramatically by the increasing use of "going public" as a strategy. Since the Constitution is an incomplete contract, the struggle for power between the three branches of government is inevitable, ${ }^{66}$ and the presidency will continue to change. However, the strategy of "going Washington" has not necessarily been replaced. Richard Neustadt's thesis has been both refuted and modified by other scholars, but in spite of its weaknesses and the development of a more rhetorical presidency, the conclusion of this article is that Neustadt's thesis does not need to be refuted. As Tulis argues, "skillful use of popular rhetoric can be integrated into a bargaining perspective if one explores the conditions under which such appeals strengthen, weaken, or substitute for traditional exchange relations" ${ }^{67}$ Even though other models may be able to describe presidential power better, Neustadt's thesis is still considered a theory that scholars need to relate to

Another important issue, to which this article may have provided some

65 Jonathan Charteris-Black, Analysing Political Speeches: Rhetoric, Discourse and Metaphor (Basingstoke, Hampshire; New York: Palgrave Macmillan, 2014), 15.

66 Terry M. Moe and William G. Howell, "Unilateral Action and Presidential Power: A Theory," Presidential Studies Quarterly 29, no. 4 (1999): 853, https://doi.org/10.1111/1741-5705.00070.

67 Tulis, The Rhetorical Presidency, 11-12. 
background, is the question of the role of public appeals in the political system. According to Charles U. Zug, "American citizens take the rhetorical presidency for granted without questioning either how it became rhetorical or whether it should be rhetorical in the first place". ${ }^{68}$ Woodrow Wilson, who arguably introduced the rhetorical presidency and a "second constitution", also seemed to have been aware of the vulnerability to demagoguery by changing the public role of the president. ${ }^{69}$ Since then the rhetorical presidency has developed gradually. Not least in light of Donald Trump's frequent appeals to emotion and his extensive use of Twitter there is reason to discuss how rhetorical the presidency should be. Alexander Hamilton's warning against "an obsequious court to the people"70 may be as relevant today as in the $18^{\text {th }}$ century.

68 Zug, "The Rhetorical Presidency Made Flesh: A Political Science Classic in the Age of Donald Trump," 350 .

69 Terri Bimes and Stephen Skowronek, "Woodrow Wilson's Critique of Popular Leadership: Reassessing the Modern-Traditional Divide in Presidential History," Polity 29, no. 1 (1996): 47, https://doi. org/10.2307/3235274.

70 Hamilton, "The Federalist No. 1." 


\section{Bibliography}

Anthony, Laurence. "Antconc." 3.5.8, 2019. https://www.laurenceanthony. net/software/ antconc/.

Bailey, Harry A. "Neustadt's Thesis Revisited: Toward the Two Faces of Presidential Power." Presidential Studies Quarterly 11, no. 3 (1981): 351-57. http://www.jstor.org/ stable/27547714.

Bimes, Terri, and Stephen Skowronek. "Woodrow Wilson's Critique of Popular Leadership: Reassessing the Modern-Traditional Divide in Presidential History." Polity 29, no. 1 (1996): 27-63. https://doi.org/10.2307/3235274.

Burke, John P. Presidential Power: Theories and Dilemmas. Boulder, CO: Westview Press, 2016.

Bush, George H. W. "Address before a Joint Session of Congress on the State of the Union “ In The American Presidency Project, edited by Gerhard Peters and John T. Woolley. Santa Barbara, CA: University of California, 1992. https://www.presidency.ucsb.edu/ documents/address-before-joint-session-the-congress-the-state-the-union-0.

Canes-Wrone, Brandice. "The President's Legislative Influence from Public Appeals." American Journal of Political Science 45, no. 2 (2001): 313-29. https://doi. org/10.2307/2669343.

Ceaser, James W., Glen E. Thurow, Jeffrey Tulis, and Joseph M. Bessette. "The Rise of the Rhetorical Presidency.” Presidential Studies Quarterly 11, no. 2 (1981): 158-71. http:// www.jstor.org/stable/27547683.

Charteris-Black, Jonathan. Analysing Political Speeches: Rhetoric, Discourse and Metaphor. Basingstoke, Hampshire; New York: Palgrave Macmillan, 2014.

- - - Politicians and Rhetoric: The Persuasive Power of Metaphor. 2nd ed. ed. Basingstoke, Hampshire; New York: Palgrave Macmillan, 2011.

Chilton, Paul A. Analysing Political Discourse: Theory and Practice. New York: Routledge, 2004.

Clinton, Bill. "Address before a Joint Session of Congress on the State of the Union "In The American Presidency Project, edited by Gerhard Peters and John T. Woolley. Santa Barbara, CA: University of California, 1997. https://www.presidency.ucsb.edu/documents/ address-before-joint-session-the-congress-the-state-the-union-9.

Crockett, David A. “"The Rhetorical Presidency": Still Standing Tall." Presidential Studies Quarterly 39, no. 4 (2009): 932-40. http://www.jstor. org/stable/41427430.

Edwards III, George C. On Deaf Ears: The Limits of the Bully Pulpit. New Haven: Yale University Press, 2003.

Eisenhower, Dwight D. "Annual Message to the Congress on the State of the Union "In The American Presidency Project, edited by Gerhard Peters and John T. Woolley. Santa Barbara, CA: University of California, 1960. https://www.presidency.ucsb.edu/documents/ annual-message-the-congress-the-state-the-union- 6 .

Genovese, Michael A. Presidential Leadership in an Age of Change. The Presidential Briefings Series. New Brunswick, NJ: Transaction Publishers, 2016.

Glaros, Roberta, and Bruce Miroff. "Watching Ronald Reagan: Viewers' Reactions to the President on Television." Congress \& the Presidency 10, no. 1 (1983): 25-46. https://doi. org/10.1080/07343468309508025.

Greenstein, Fred I. "Introduction: Toward a Modern Presidency." In Leadership in the Modern Presidency, edited by Fred I. Greenstein, 1-6. Cambridge, MA: Harvard University Press, 1988.

Hamilton, Alexander. "The Federalist No. 1.” In The Federalist, edited by Jacob E. Cooke, 3-7. Middletown, CT: Wesleyan University Press, 1788/1961. 
Johnson, Lyndon B. "Annual Message to the Congress on the State of the Union "In The American Presidency Project, edited by Gerhard Peters and John T. Woolley. Santa Barbara, CA: University of California, 1964. https:/www. presidency.ucsb.edu/documents/ annual-message-the-congress-the-state-the-union- 25 .

- - - . "Annual Message to the Congress on the State of the Union "In The American Presidency Project, edited by Gerhard Peters and John T. Woolley. Santa Barbara, CA: University of California, 1969. https://www. presidency.ucsb.edu/documents/annualmessage-the-congress-the-state-the-union- 30 .

Jones, Charles O. "Professional Reputation and the Neustadt Formulation." Presidential Studies Quarterly 31, no. 2 (2001): 281-95. https://doi.org/ 10.1111/j.03604918.2001.00171.x.

- - - "Richard E. Neustadt: Public Servant as Scholar." Annual Review of Political Science 6, no. 1 (2003): 1-22. https://doi.org/10.1146/annurev. polisci.6.121901.085848.

Kennedy, John F. "Annual Message to the Congress on the State of the Union "In The American Presidency Project, edited by Gerhard Peters and John T. Woolley. Santa Barbara, CA: University of California, 1963. https://www. presidency.ucsb.edu/documents/ annual-message-the-congress-the-state-the-union-3.

Kernell, Samuel. Going Public: New Strategies of Presidential Leadership. Washington, D.C.: CQ Press, 1986.

- - - Going Public: New Strategies of Presidential Leadership. 4th ed. Washington, D.C.: CQ Press, 2007. Table of contents only http://www.loc. gov/catdir/toc/ ecip072/2006032005.html.

Kleinerman, Benjamin A. "The Constitutional Ambitions of James Madison's Presidency." Presidential Studies Quarterly 44, no. 1 (2014): 6-26. https://doi.org/10.1111/psq.12085.

Madison, James. “The Federalist No. 49.” In The Federalist, edited by Jacob E. Cooke, 33843. Middletown, CT: Wesleyan University Press, 1788/1961.

Medhurst, Martin J. "Introduction - a Tale of Two Constructs: The Rhetorical Presidency and Presidential Rhetoric." In Beyond the Rhetorical Presidency, edited by Martin J. Medhurst. College Station: Texas A\&M University Press, 1996.

Moe, Terry M., and William G. Howell. "Unilateral Action and Presidential Power: A Theory.” Presidential Studies Quarterly 29, no.4 (1999): 850-73. https://doi.org/10.1111/17415705.00070 .

Neustadt, Richard E. Presidential Power: The Politics of Leadership. New York: Wiley, 1960.

Obama, Barack. "Address before a Joint Session of Congress on the State of the Union "In The American Presidency Project, edited by Gerhard Peters and John T. Woolley. Santa Barbara, CA: University of California, 2015. https://www.presidency.ucsb.edu/documents/address-before-joint-session-the-congress-the-state-the-union-20.

Peters, Gerhard, and John T. Wooley. "The State of the Union, Background and Reference Table." In The American Presidency Project, edited by Gerhard Peters and John T. Wooley. Santa Barbara, CA: University of California, 1999-2020. https://www.presidency. ucsb.edu/node/324107/.

Reagan, Ronald. "Address before a Joint Session of Congress Reporting on the State of the Union " In The American Presidency Project, edited by Gerhard Peters and John T. Woolley. Santa Barbara, CA: University of California, 1982. https://www.presidency. ucsb.edu/documents/address-before-joint-session-the-congress-reporting-the-state-theunion-2.

Roosevelt, Franklin D. "Annual Message to Congress “ In The American Presidency Project, edited by Gerhard Peters and John T. Woolley. Santa Barbara, CA: University of Cal- 
ifornia, 1942. https://www.presidency.ucsb.edu/documents /state-the-union-address-1 .

_ _ - . "Annual Message to Congress " In The American Presidency Project, edited by Gerhard Peters and John T. Woolley. Santa Barbara, CA: University of California, 1943. https://www.presidency.ucsb.edu/documents/state-the-union-address-0.

- _ _ . "Annual Message to Congress " In The American Presidency Project, edited by Gerhard Peters and John T. Woolley. Santa Barbara, CA: University of California, 1937. https://www.presidency.ucsb.edu/documents/annual-message-congress-1.

- - _ . "Annual Message to Congress " In The American Presidency Project, edited by Gerhard Peters and John T. Woolley. Santa Barbara, CA: University of California, 1934. https://www.presidency.ucsb.edu/documents/annual-message-congress-4.

Rozell, Mark J. “In Reagan's Shadow: Bush's Antirhetorical Presidency.” Presidential Studies Quarterly 28, no. 1 (1998): 127-38. http://www.jstor. org/stable/27551835.

Schlesinger, Arthur M. The Imperial Presidency. Boston: Houghton Mifflin, 1973.

Schlesinger, Arthur M., Jr. The Crisis of the Old Order: The Age of Roosevelt, 1919-1933. Francis Parkman Prize ed. New York: History Book Club, 1957/2002. 1957.

Sollenberger, Mitchel A. "The Law Presidential Studies, Behavioralism, and Public Law.” Presidential Studies Quarterly 44, no. 4 (2014): 758-78. https://doi.org/10.1111/ psq.12159.

Teten, Ryan L. "Evolution of the Modern Rhetorical Presidency: Presidential Presentation and Development of the State of the Union Address." Presidential Studies Quarterly 33, no. 2 (2003): 333-46. https://doi.org/ 10.1111/j.1741-5705.2003.tb00033.x.

Truman, Harry. "Annual Message to the Congress on the State of the Union "In The American Presidency Project, edited by Gerhard Peters and John T. Woolley. Santa Barbara, CA: University of California, 1947. https://www. presidency.ucsb.edu/documents/annual-message-the-congress-the-state-the-union- 15 .

Trump, Donald J. "Address before a Joint Session of Congress on the State of the Union "In The American Presidency Project, edited by Gerhard Peters and John T. Woolley. Santa Barbara, CA: University of California, 2018. https://www.presidency.ucsb.edu/ documents/address-before-joint-session-the-congress-the-state-the-union- 25.

- - - . "Address before a Joint Session of Congress on the State of the Union "In The American Presidency Project, edited by Gerhard Peters and John T. Woolley. Santa Barbara, CA: University of California, 2020. https://www.presidency.ucsb.edu/documents/ address-before-joint-session-the-congress-the-state-the-union-27.

Tulis, Jeffrey K. The Rhetorical Presidency. Princeton, NJ: Princeton University Press, 1987. Zug, Charles U. "The Rhetorical Presidency Made Flesh: A Political Science Classic in the Age of Donald Trump." Critical Review 30, no. 3-4 (2018/10/02 2018): 347-68. https:// doi.org/10.1080/08913811.2018.1567983. 